\title{
Seismic Performance and Cost Comparison of Concentrically Braced Frames Designed By Performance-Based Plastic Design and Force-Based Design Method
}

\author{
Sejal P Dalal, Khyati Vaidya
}

\begin{abstract}
Comparative study of 5, 10 and 15 storied steel Concentrically Braced Frames (CBF) designed by Performance Based Plastic Design (PBPD) method and Force Based Design (FBD) method is presented here. The parameters selected for comparison of the frames are (a) Lateral load distribution (b) Design sections of members (c) Seismic performance and (d) Cost. It is observed that the lateral load's distribution in case of $P B P D$ frames is found more factual. The column sections of $P B P D$ frames are heavier, and brace sections are lighter compared to $F B D$ frames given the fact that $P B P D$ is designed for higher ductility factor. The PBPD method gives a better seismic performance by achieving the predetermined failure mechanism and avoiding total collapse. Taller structures offer cost-effectiveness for PBPD method.
\end{abstract}

\section{Keywords: Performance-Based Plastic Design method}

Force Based Design Method Concentrically Braced Frames

Seismic PerformancePerformance Point

\section{INTRODUCTION}

The PBPD method is a displacement based design method which is based on Energy Balance Concept (1, 2). Pre-selected target drift and yield mechanism are the main performance criteria which prevent the total collapse of the structure. When CBF's are designed using this method, the braces fail first due to post-buckling and tension yielding thus leading to the formation of plastic hinges $(3,4)$. The beams are designed as yielding members whereas columns are designed as unyielding members and hence the total collapse can be prevented.

In the FBD method, the structure is designed for forces and checked for displacements assuming that it will remain elastic all the time. The failure is unpredictable and at times sudden because the inelastic activity in the structure is addressed in an approximate way [5]. In this study, three CBF's of different heights but same plan are first analyzed by both the methods and then designed using Indian standard specifications.

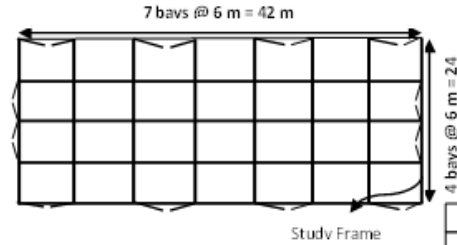

(a)
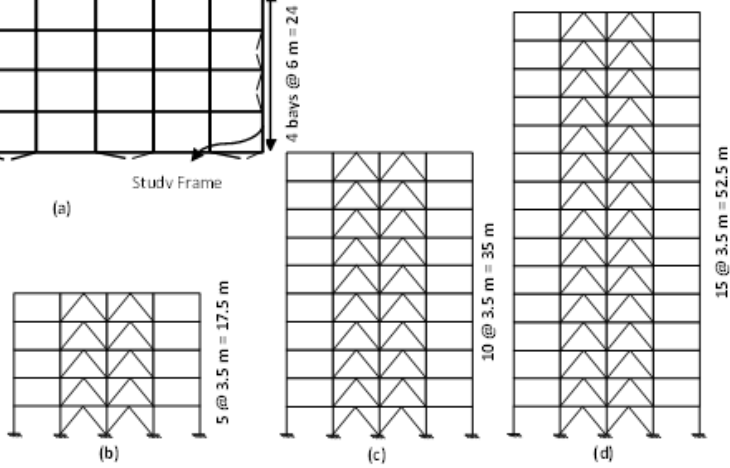

Figure1. (a) Plan of the study frame; (b) 5 storied frame; (c) 10 storied frame; (d) 15 storied frame.

Table1. The seismic parameters and details of study frame for the FBD method.

\begin{tabular}{|l|l|l|l|}
\hline Parameter & 5 Storey & 10 Storey & 15 Storey \\
\hline Floor Seismic Weight for roof (kN) & 280 & 280 & 280 \\
\hline Floor Seismic Weight for other floors $(\mathrm{kN})$ & 439 & 439 & 439 \\
\hline Total seismic weight, W (kN) & 2036 & 4231 & 6426 \\
\hline Time Period, Tn (sec) & 0.72 & 1.22 & 1.65 \\
\hline Sa & 1.86 & 1.11 & 0.82 \\
\hline Zone factor (III), Z & 0.24 & 0.24 & 0.24 \\
\hline Importance factor, I & 1.5 & 1.5 & 1.5 \\
\hline Response Reduction Factor, R & 4 & 4 & 4 \\
\hline Ah & 0.08 & 0.05 & 0.036 \\
\hline Vb (kN) & 171.4 & 211.8 & 237.3 \\
\hline Vb/W & 0.08 & 0.05 & 0.03 \\
\hline
\end{tabular}

Revised Manuscript Received on July 22, 2019.

Sejal P Dalal, Civil Engineering Department, Sardar Vallabhbhai Patel Institute of Technology (SVIT), Vasad, Gujarat-388306, India.

Khyati Vaidya, Civil Engineering Department, Sardar Vallabhbhai Patel Institute of Technology (SVIT), Vasad, Gujarat-388306, India.

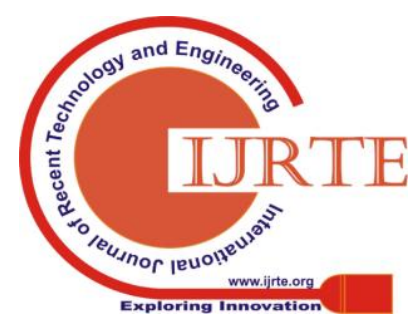




\section{Seismic Performance and Cost Comparison of Concentrically Braced Frames Designed By Performance-Based Plastic Design and Force-Based Design Method}

Figure 1 shows the plan as well as the elevation of the 5,10 and 15 storied study frame. The live load for a typical floor is taken as $3.5 \mathrm{kN} / \mathrm{m}^{2}$ and for the roof is taken as $1.5 \mathrm{kN} / \mathrm{m}^{2}$. The Floor finish is assumed to be $1 \mathrm{kN} / \mathrm{m}^{2}$, and the soil site is of medium type. The important seismic design parameters required to analyze the frames by FBD method are listed in table 1 and for PBPD in table 2.

Table 2. The seismic parameters and details of study frame for the PBPD method.

\begin{tabular}{|l|l|l|lr|}
\hline Parameter & 5 Storey & 10 Storey & 15 Storey & ex \\
\hline Floor Seismic Weight for roof $(\mathrm{kN})$ & 280 & 280 & 280 & $\mathrm{p}$ \\
\hline $\begin{array}{l}\text { Floor Seismic Weight for other floors } \\
(\mathrm{kN})\end{array}$ & 439 & 439 & 439 & 0 \\
\hline Total seismic weight, W $(\mathrm{kN})$ & 2036 & 4231 & 6426 & \\
\hline Time Period, Tn (sec) & 0.72 & 1.22 & 1.65 & \\
\hline $\mathrm{Sa}$ & 1.86 & 1.11 & 0.82 & $\mathrm{r}$ \\
\hline Zone factor (III), Z & 0.24 & 0.24 & 0.24 & \\
\hline Importance factor, I & 1.5 & 1.5 & 1.5 & \\
\hline Response Reduction Factor, R & 4 & 4 & 4 & $(0.5$ \\
\hline $\mathrm{Ah}$ & 0.08 & 0.05 & 0.036 & $\mathrm{~F}$ \\
\hline $\mathrm{Vb}(\mathrm{kN})$ & 171.4 & 211.8 & 237.3 & \\
\hline $\mathrm{Vb} / \mathrm{W}$ & 0.08 & 0.05 & 0.03 & \\
\hline
\end{tabular}

\section{Lateral Load}

\subsection{Lateral Load Calculation and Distribution in forced based design method}

Mathematically, the total design base shear "Vb" in the FBD method is calculated by distributing the total weight "W" as per IS 1893:2002 (6) as follows.

$$
\begin{aligned}
& \mathrm{V}_{\mathrm{b}}=\mathrm{A}_{\mathrm{h}} \mathrm{W} \\
& \mathrm{A}_{\mathrm{h}}=\frac{\mathrm{zI}\left(S_{\mathrm{z}} \mathrm{g}\right)}{2 \mathrm{R}}
\end{aligned}
$$

Here, the Horizontal seismic coefficient "Ah"is dependent on Zone factor "Z", Importance factor "I", Design spectral acceleration " $\mathrm{Sa} / \mathrm{g}$ " and response reduction factors " $\mathrm{R}$ ". This base shear is distributed among the floors known as the lateral force distribution at each floor level, "Qi" as per following equation (6).

$$
\mathrm{Q}_{\mathrm{i}}=\mathrm{V}_{\mathrm{b}} \frac{\mathrm{w}_{\mathrm{i}} \mathrm{h}_{\mathrm{i}}^{2}}{\sum_{\mathrm{i}=1}^{\mathrm{n}} \mathrm{w}_{\mathrm{i}}} \mathrm{h}_{\mathrm{i}}^{2}
$$

Where, hi (and hn)= Height of level i (and roof )measured from base wi (and wn)=Seismic weight of level i (and roof)

\subsection{Lateral Load Calculation and distribution in PBPD method}

The total base shear " $\mathrm{V}_{\mathrm{b}}$ " in the PBPD method is calculated based on work energy equation (1) and is expressed as

$$
V_{b}=\left(\frac{-A_{h}+\sqrt{A_{h}^{2}+4\left(\frac{V}{W}\right) s_{\text {ainalastic }}^{2}}}{2}\right) W
$$

$$
A_{h}=\left(\sum_{i=1}^{n}\left(\beta_{i}-\beta_{i+1}\right) h_{i}\right)\left(\frac{w_{m} h_{m}}{\Sigma_{i=1}^{n} w_{i} h_{i}}\right)^{0.75 T_{m}^{-1.4}}\left(\frac{\theta_{p} 9 \pi^{2}}{T_{m}^{2} g}\right)
$$

$$
\beta_{\mathrm{i}}=\left(\frac{\sum_{\mathrm{i}=1}^{n} W_{i} h_{\mathrm{i}}}{W_{m} h_{n}}\right)^{0.75 T_{m}{ }^{-0.2}}
$$

Where, $\beta \mathrm{i}=$ Shear distribution factor (7).

$\gamma=$ Energy modification factor (fig.2) (8)

$\eta=a$ factor used to find modified base shear considering extra energy which is dissipated by $\mathrm{CBF}$ as well as the participation of gravity frames in resisting earthquake loads $=$ $0.5 .(1,3)$

Sa inelastic $=$ Design Spectral acceleration due to inelastic esponse of structure as (fig.2) (8)

$\theta_{\mathrm{p}}=$ the selected global inelastic drift of the structure $\left.\theta_{\text {pax }}-\theta_{y}\right)$, i.e. predetermined target drift mechanism.

Figure 2. (a) Inelastic Response spectra for medium soil site

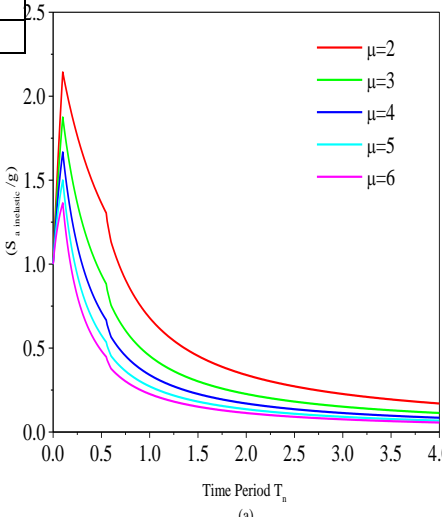

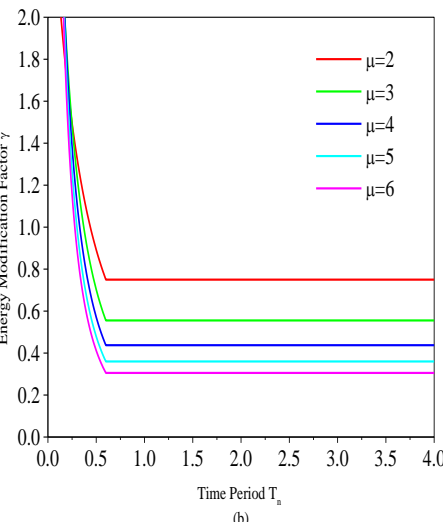

in the AT format; (b) Energy Modification Factor " $\gamma$ " Versus Time Period.

The base shear in the PBPD method is divided by the number of bays falling in the direction perpendicular to the lateral load (1). Thus we get a term " $\mathrm{V}$ "' which is the total base shear "Vb" divided by a number of bays. The lateral force of roof floor "Qn" is first found and then it is distributed in other floors "Qi" as shown below $(1,7)$

$$
\begin{aligned}
& Q_{n}=\frac{V^{\prime}}{\sum\left(\beta_{i}-\beta_{i+1}\right)} \\
& Q_{i}=Q_{n}\left(\beta_{i}-\beta_{i+1}\right)
\end{aligned}
$$

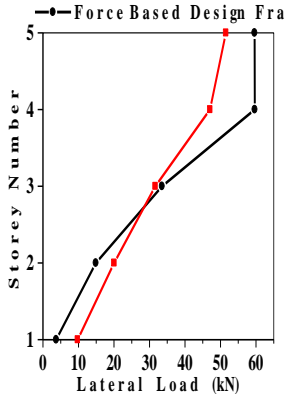

(a)

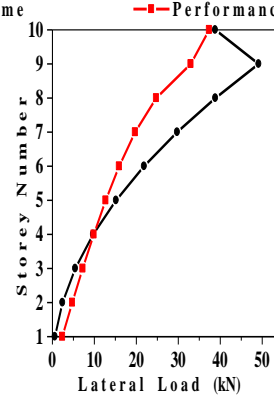

(b)

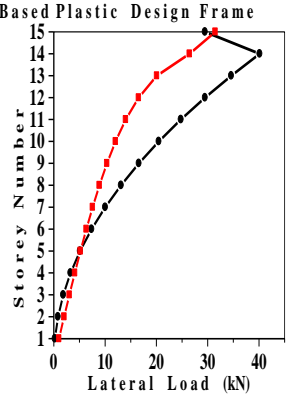

(c)

Figure 3. Lateral Load Distribution for both the methods of

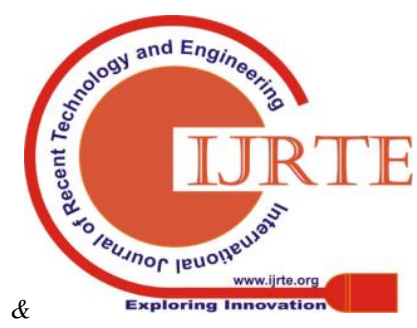


(a) 5 storied frame; (b) 10 storied frame; (c) 15 storied frame.

The lateral load distribution of 5,10 and 15 storied frames designed by both the methods have been presented in fig.3.It is clearly seen that PBPD method gives more even distribution of loads as compared to FBD method. The values of a lateral load of the roof floor are lesser compared to the succeeding floor in the FBD method particularly in taller frames (10 and 15 storied) which seems to be peculiar. It does not happen in PBPD frames because higher mode effects are well reflected in the design lateral force distribution (7).The frames are applied the above calculated lateral loads along with gravity loads.

\section{DESIGN DETAILS OF THE FRAMES}

Table 3. The design sections of 5 storied study frame.

\begin{tabular}{|c|c|c|c|c|c|c|}
\hline & \multicolumn{3}{|c|}{ PBPD Method } & \multicolumn{3}{|c|}{ FBD Method } \\
\hline $\begin{array}{l}\text { Storey } \\
\text { No }\end{array}$ & $\begin{array}{l}\text { Brace } \\
\text { Section }\end{array}$ & $\begin{array}{l}\text { Beam } \\
\text { Section }\end{array}$ & $\begin{array}{l}\text { Column } \\
\text { section }\end{array}$ & $\begin{array}{l}\text { Brace } \\
\text { Section }\end{array}$ & $\begin{array}{l}\text { Beam } \\
\text { Section }\end{array}$ & $\begin{array}{l}\text { Column } \\
\text { section }\end{array}$ \\
\hline 5 & $\begin{array}{c}\text { 2ISA } 30 \\
204\end{array}$ & $\begin{array}{c}\text { ISMB } \\
400\end{array}$ & $\begin{array}{c}\text { ISHB } \\
150\end{array}$ & $\begin{array}{c}\text { TUB } 89 \\
894\end{array}$ & $\begin{array}{c}\text { ISMB } \\
350\end{array}$ & $\begin{array}{c}\text { ISHB } \\
150\end{array}$ \\
\hline 4 & $\begin{array}{c}\text { 2ISA } 45 \\
305\end{array}$ & $\begin{array}{c}\text { ISMB } \\
500\end{array}$ & $\begin{array}{c}\text { ISHB } \\
200\end{array}$ & $\begin{array}{c}\text { TUB } 89 \\
894\end{array}$ & $\begin{array}{c}\text { ISMB } \\
400\end{array}$ & $\begin{array}{c}\text { ISHB } \\
200\end{array}$ \\
\hline 3 & $\begin{array}{c}\text { 2ISA } 60 \\
405\end{array}$ & $\begin{array}{c}\text { ISMB } \\
500\end{array}$ & $\begin{array}{c}\text { ISHB } \\
250\end{array}$ & $\begin{array}{c}\text { TUB } \\
100100 \\
4\end{array}$ & $\begin{array}{c}\text { ISMB } \\
450\end{array}$ & $\begin{array}{c}\text { ISHB } \\
250\end{array}$ \\
\hline 2 & $\begin{array}{c}\text { 2ISA } 60 \\
405\end{array}$ & $\begin{array}{c}\text { ISWB } \\
500\end{array}$ & $\begin{array}{c}\text { ISHB } \\
300\end{array}$ & $\begin{array}{c}\text { TUB } \\
100100 \\
4\end{array}$ & $\begin{array}{c}\text { ISMB } \\
450\end{array}$ & $\begin{array}{c}\text { ISHB } \\
350\end{array}$ \\
\hline 1 & $\begin{array}{c}\text { 2ISA } 65 \\
455\end{array}$ & $\begin{array}{c}\text { ISWB } \\
500\end{array}$ & $\begin{array}{c}\text { ISHB } \\
450\end{array}$ & $\begin{array}{c}\text { TUB } \\
100100 \\
5\end{array}$ & $\begin{array}{c}\text { ISMB } \\
400\end{array}$ & $\begin{array}{c}\text { ISHB } \\
400\end{array}$ \\
\hline
\end{tabular}

Table 4. The design sections of 10 storied study frame.

\begin{tabular}{|c|c|c|c|c|c|c|}
\hline & \multicolumn{3}{|c|}{ PBPD Method } & \multicolumn{3}{|c|}{ FBD Method } \\
\hline $\begin{array}{l}\text { Storey } \\
\text { No }\end{array}$ & $\begin{array}{l}\text { Brace } \\
\text { Section }\end{array}$ & $\begin{array}{l}\text { Beam } \\
\text { Section }\end{array}$ & $\begin{array}{l}\text { Column } \\
\text { section }\end{array}$ & $\begin{array}{l}\text { Brace } \\
\text { Section }\end{array}$ & $\begin{array}{l}\text { Beam } \\
\text { Section }\end{array}$ & $\begin{array}{l}\text { Column } \\
\text { section }\end{array}$ \\
\hline 10 & $\begin{array}{l}\text { 2ISA } 30 \\
203\end{array}$ & $\begin{array}{l}\text { ISMB } \\
400\end{array}$ & ISHB 150 & $\begin{array}{l}\text { TUB } \\
100100 \\
4\end{array}$ & $\begin{array}{l}\text { ISMB } \\
350\end{array}$ & ISHB 150 \\
\hline 9 & $\begin{array}{l}\text { 2ISA } 50 \\
304\end{array}$ & $\begin{array}{l}\text { ISMB } \\
500\end{array}$ & $\begin{array}{l}\text { ISHB } \\
150 \mathrm{H}\end{array}$ & $\begin{array}{l}\text { TUB } \\
100100 \\
5\end{array}$ & $\begin{array}{l}\text { ISMB } \\
500\end{array}$ & $\begin{array}{l}\text { ISHB } \\
150 \mathrm{H}\end{array}$ \\
\hline 8 & $\begin{array}{l}\text { 2ISA } 45 \\
305\end{array}$ & $\begin{array}{l}\text { ISMB } \\
500\end{array}$ & ISHB 200 & $\begin{array}{l}\text { TUB } \\
100100 \\
5\end{array}$ & $\begin{array}{l}\text { ISMB } \\
550\end{array}$ & $\begin{array}{l}\text { ISHB } \\
250 \mathrm{H}\end{array}$ \\
\hline 7 & $\begin{array}{l}\text { 2ISA } 45 \\
306\end{array}$ & $\begin{array}{l}\text { ISMB } \\
500\end{array}$ & ISHB 250 & $\begin{array}{l}\text { TUB } \\
100100 \\
5\end{array}$ & $\begin{array}{l}\text { ISMB } \\
550\end{array}$ & ISHB 350 \\
\hline 6 & $\begin{array}{l}\text { 2ISA } 60 \\
405\end{array}$ & $\begin{array}{l}\text { ISMB } \\
500\end{array}$ & $\begin{array}{l}\text { ISHB } \\
300 \mathrm{H}\end{array}$ & $\begin{array}{l}\text { TUB } \\
100100 \\
5\end{array}$ & $\begin{array}{l}\text { ISMB } \\
500\end{array}$ & ISHB 400 \\
\hline 5 & $\begin{array}{l}\text { 2ISA } 60 \\
405\end{array}$ & $\begin{array}{l}\text { ISWB } \\
500\end{array}$ & $\begin{array}{l}\text { ISHB } \\
350 \mathrm{H}\end{array}$ & $\begin{array}{l}\text { TUB } \\
113113 \\
5\end{array}$ & $\begin{array}{l}\text { ISMB } \\
500\end{array}$ & ISHB 450 \\
\hline 4 & $\begin{array}{l}\text { 2ISA } 65 \\
455\end{array}$ & $\begin{array}{l}\text { ISWB } \\
500\end{array}$ & ISHB 450 & $\begin{array}{l}\text { TUB } \\
130130 \\
5\end{array}$ & $\begin{array}{l}\text { ISMB } \\
550\end{array}$ & ISHB 450 \\
\hline
\end{tabular}

\begin{tabular}{|c|l|l|l|l|l|l|}
\hline $3 \& 2$ & $\begin{array}{l}\text { 2ISA 65 } \\
455\end{array}$ & $\begin{array}{l}\text { ISMB } \\
550\end{array}$ & $\begin{array}{l}\text { ISHB 450 } \\
\text { with } \\
250 \times 12 \\
\text { CP }\end{array}$ & $\begin{array}{l}\text { TUB } \\
130130 \\
5\end{array}$ & $\begin{array}{l}\text { ISMB } \\
550\end{array}$ & $\begin{array}{l}\text { ISHB } \\
450 \mathrm{H}\end{array}$ \\
\hline 1 & $\begin{array}{l}\text { ISA 65 } \\
455\end{array}$ & $\begin{array}{l}\text { ISWB } \\
550\end{array}$ & $\begin{array}{l}\text { ISHB 450 } \\
\text { with } \\
320 \times 12\end{array}$ & $\begin{array}{l}\text { TUB } \\
130130\end{array}$ & $\begin{array}{l}\text { ISMB } \\
\text { CP }\end{array}$ & $\begin{array}{l}\text { ISHB 450 } \\
\text { with } \\
250 \times 12 \\
\text { CP }\end{array}$ \\
\hline
\end{tabular}

Table 5. The design sections of 15 storied study frame.

\begin{tabular}{|c|c|c|c|c|c|c|}
\hline & \multicolumn{3}{|c|}{ PBPD Method } & \multicolumn{3}{|c|}{ FBD Method } \\
\hline $\begin{array}{l}\text { Storey } \\
\text { No }\end{array}$ & $\begin{array}{l}\text { Brace } \\
\text { Section }\end{array}$ & $\begin{array}{l}\text { Beam } \\
\text { Section }\end{array}$ & $\begin{array}{l}\text { Column } \\
\text { section }\end{array}$ & $\begin{array}{l}\text { Brace } \\
\text { Section }\end{array}$ & $\begin{array}{l}\text { Beam } \\
\text { Section }\end{array}$ & $\begin{array}{l}\text { Column } \\
\text { section }\end{array}$ \\
\hline 15 & $\begin{array}{l}\text { 2ISA } 30 \\
203\end{array}$ & $\begin{array}{l}\text { ISMB } \\
400\end{array}$ & ISHB 150 & $\begin{array}{l}\text { TUB } 100 \\
1005\end{array}$ & $\begin{array}{l}\text { ISMB } \\
350\end{array}$ & ISHB 200 \\
\hline 14 & $\begin{array}{l}\text { 2ISA } 30 \\
205\end{array}$ & $\begin{array}{l}\text { ISMB } \\
450\end{array}$ & ISHB 150H & $\begin{array}{l}\text { TUB } 100 \\
1005\end{array}$ & $\begin{array}{l}\text { ISMB } \\
500\end{array}$ & ISHB 300 \\
\hline $13 \& 12$ & $\begin{array}{l}\text { 2ISA } 45 \\
305\end{array}$ & $\begin{array}{l}\text { ISMB } \\
500\end{array}$ & ISHB 250 & $\begin{array}{l}\text { TUB } 100 \\
1005\end{array}$ & $\begin{array}{l}\text { ISMB } \\
500\end{array}$ & ISHB 350 \\
\hline 11 & $\begin{array}{l}\text { 2ISA } 45 \\
306\end{array}$ & $\begin{array}{l}\text { ISMB } \\
500\end{array}$ & ISHB 300 & $\begin{array}{l}\text { TUB } 100 \\
1005\end{array}$ & $\begin{array}{l}\text { ISMB } \\
550\end{array}$ & ISHB 400 \\
\hline 10 & $\begin{array}{l}\text { 2ISA } 45 \\
306\end{array}$ & $\begin{array}{l}\text { ISMB } \\
500\end{array}$ & ISHB 350 & $\begin{array}{l}\text { TUB } 113 \\
1135\end{array}$ & $\begin{array}{l}\text { ISMB } \\
600\end{array}$ & ISHB 450 \\
\hline 9 & $\begin{array}{l}\text { 2ISA } 60 \\
405\end{array}$ & $\begin{array}{l}\text { ISMB } \\
550\end{array}$ & ISHB 450 & $\begin{array}{l}\text { TUB } 113 \\
1135\end{array}$ & $\begin{array}{l}\text { ISMB } \\
600\end{array}$ & ISHB $450 \mathrm{H}$ \\
\hline 8 & $\begin{array}{l}\text { 2ISA } 60 \\
405\end{array}$ & $\begin{array}{l}\text { ISMB } \\
550\end{array}$ & $\begin{array}{l}\text { ISHB } 450 \\
\text { with } 320 \times 12 \\
\text { CP }\end{array}$ & $\begin{array}{l}\text { TUB } 110 \\
1106\end{array}$ & $\begin{array}{l}\text { ISMB } \\
550\end{array}$ & $\begin{array}{l}\text { ISHB } 450 \text { with } \\
250 \times 12 \mathrm{CP}\end{array}$ \\
\hline 7 & $\begin{array}{l}\text { 2ISA } 60 \\
405\end{array}$ & $\begin{array}{l}\text { ISMB } \\
550\end{array}$ & $\begin{array}{l}\text { ISHB } 450 \\
\text { with } 320 \times 12 \\
\text { CP }\end{array}$ & $\begin{array}{l}\text { TUB } 110 \\
1106\end{array}$ & $\begin{array}{l}\text { ISMB } \\
550\end{array}$ & $\begin{array}{l}\text { ISHB } 450 \text { with } \\
250 \times 12 \mathrm{CP}\end{array}$ \\
\hline 6 & $\begin{array}{l}\text { 2ISA } 65 \\
455\end{array}$ & $\begin{array}{l}\text { ISMB } \\
550\end{array}$ & $\begin{array}{l}\text { ISHB } 450 \\
\text { with } 320 \times 12 \\
\text { CP }\end{array}$ & $\begin{array}{l}\text { TUB } 110 \\
1106\end{array}$ & $\begin{array}{l}\text { ISMB } \\
550\end{array}$ & $\begin{array}{l}\text { ISHB } 450 \text { with } \\
320 \times 12 \mathrm{CP}\end{array}$ \\
\hline 5 & $\begin{array}{l}\text { 2ISA } 65 \\
455\end{array}$ & $\begin{array}{l}\text { ISMB } \\
550\end{array}$ & $\begin{array}{l}\text { ISHB } 450 \\
\text { with } 320 \times 12 \\
\text { CP }\end{array}$ & $\begin{array}{l}\text { TUB } 110 \\
1106\end{array}$ & $\begin{array}{l}\text { ISMB } \\
550\end{array}$ & $\begin{array}{l}\text { ISHB } 450 \text { with } \\
250 \times 16 \mathrm{CP}\end{array}$ \\
\hline 4 & $\begin{array}{l}\text { 2ISA } 65 \\
455\end{array}$ & $\begin{array}{l}\text { ISWB } \\
550\end{array}$ & $\begin{array}{l}\text { ISHB } 450 \\
\text { with } 400 \times 12 \\
\text { CP }\end{array}$ & $\begin{array}{l}\text { TUB } 132 \\
1326\end{array}$ & $\begin{array}{l}\text { ISMB } \\
500\end{array}$ & $\begin{array}{l}\text { ISHB } 450 \text { with } \\
250 \times 16 \mathrm{CP}\end{array}$ \\
\hline 3 & $\begin{array}{l}\text { 2ISA } 65 \\
455\end{array}$ & $\begin{array}{l}\text { ISWB } \\
550\end{array}$ & $\begin{array}{l}\text { ISHB } 450 \\
\text { with } 400 \times 12 \\
\text { CP }\end{array}$ & $\begin{array}{l}\text { TUB } 132 \\
1326\end{array}$ & $\begin{array}{l}\text { ISMB } \\
500\end{array}$ & $\begin{array}{l}\text { ISHB } 450 \text { with } \\
250 \times 20 \mathrm{CP}\end{array}$ \\
\hline 2 & $\begin{array}{l}\text { 2ISA } 65 \\
455\end{array}$ & $\begin{array}{l}\text { ISWB } \\
550\end{array}$ & $\begin{array}{l}\text { ISHB } 450 \\
\text { with } 320 \times 20 \\
\text { CP }\end{array}$ & $\begin{array}{l}\text { TUB } 132 \\
1326\end{array}$ & $\begin{array}{l}\text { ISMB } \\
450\end{array}$ & $\begin{array}{l}\text { ISHB } 450 \text { with } \\
320 \times 16 \mathrm{CP}\end{array}$ \\
\hline 1 & $\begin{array}{l}\text { 2ISA } 65 \\
455\end{array}$ & $\begin{array}{l}\text { ISWB } \\
550\end{array}$ & $\begin{array}{l}\text { ISHB } 450 \\
\text { with } 320 \times 25 \\
\text { CP }\end{array}$ & $\begin{array}{l}\text { TUB } 132 \\
1326\end{array}$ & $\begin{array}{l}\text { ISMB } \\
400\end{array}$ & $\begin{array}{l}\text { ISHB } 450 \text { with } \\
320 \times 16 \mathrm{CP}\end{array}$ \\
\hline
\end{tabular}

Note: $\mathrm{CP}$ indicates Cover Plates and all dimensions in $\mathrm{mm}$

In case of FBD method, static analysis is carried out by applying the lateral load at all the joints of all the bays on each floor. It means that the frame is assumed to remain connected as a continuous system. Whereas the PBPD method uses a pre-selected target drift and yield mechanism (in which braces fail first, and plastic
Published By:

Blue Eyes Intelligence Engineering \& Sciences Publication

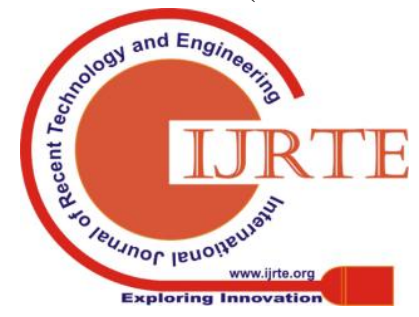




\section{Seismic Performance and Cost Comparison of Concentrically Braced Frames Designed By Performance-Based Plastic Design and Force-Based Design Method}

hinges are formed) and then the analysis is carried out by the method as suggested by $(1,5)$.The design for all frames is then done by the limit state design approach as per the specifications of IS800:2007 (9). The design details of all the frames are presented in tables 3, 4 and 5.From tables 3, 4 and 5 it is found that the brace sections of the PBPD frames are lighter compared to FBD frames. Further, the columns sections of the PBPD frames are heavier compared to FBD method.

\section{Seismic Performance Evaluation by Pushover ANALYSIS}

In order to compare the seismic performance of both the methods, nonlinear static push over analysis was carried out using SAP2000 software (10). The graph of base shear versus roof displacement obtained from software when converted to acceleration-displacement (AD) format become capacity curve and it represents the strength and deformation capacity of the structure. The elastic/inelastic design spectra in the acceleration-time (AT) format when converted to acceleration-displacement (AD) format become demand curves (11). The demand curve for the FBD frame is the elastic response spectra of IS1893:2002(6) converted in the $\mathrm{AD}$ format with $\mu$ as 1 . The demand curve for the PBPD frame is the inelastic response spectra of fig. 2 converted in the $\mathrm{AD}$ format with $\mu$ as 4 . The Indian standard code(6)has a period range from 0 to 4 seconds and hence the spectral displacement ranges from 0 to $0.137 \mathrm{~m}$ only for both elastic as well as inelastic design spectra. The intersection of the capacity curve and demand curve gives the performance point. In other words, performance point is the point where capacity equals demand. Performance point exists for all PBPD frames, whereas the performance point does not exist for 15 storied FBD frame. It means 15 storied FBD frame may fail during an earthquake event. From figure 4, it can be seen that the PBPD method gives a stiffer design, particularly for lower storey heights. Figure 5 shows the pattern of hinge formation in the study frames. It is observed that no column hinges were developed in PBPD frame and predetermined failure pattern is achieved. However, in the FBD frame, hinges were formed in columns, which indicate undesirable failure mechanism.
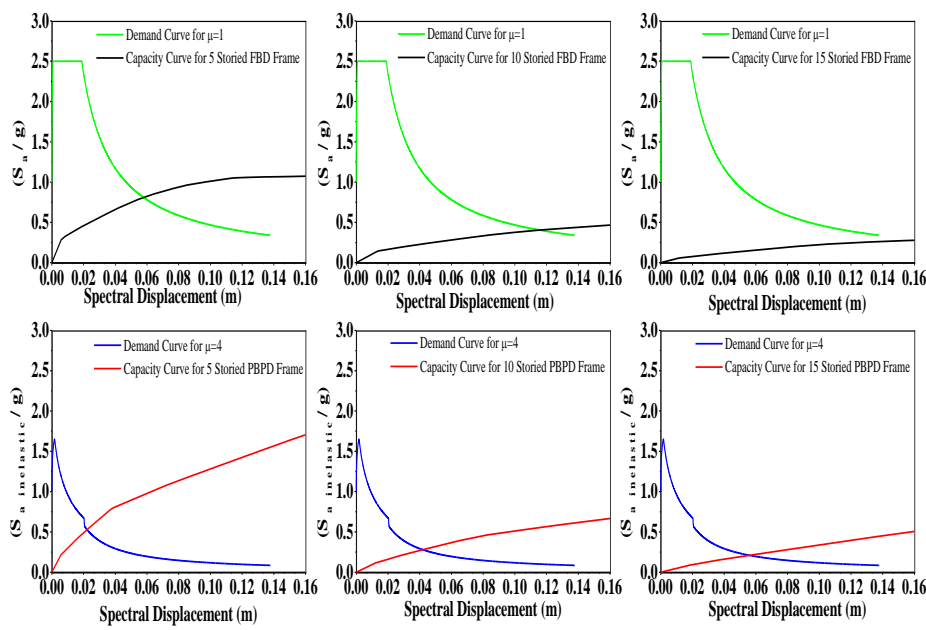

Spectral Displacement (m)

FIGURE4. THE CAPACITY DEMAND CURVES FOR ALL
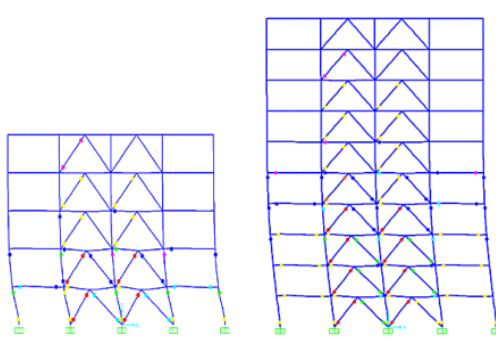

(a)

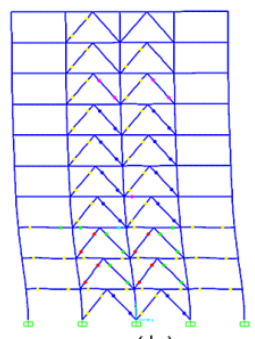

(b)

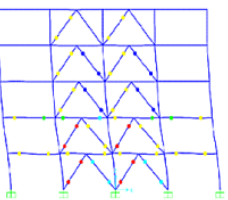

- Elastic Deformation

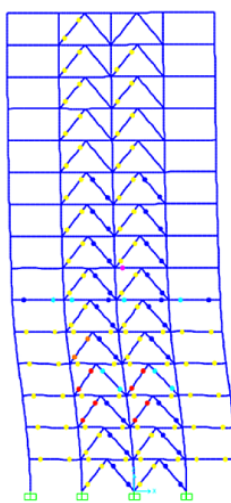

FRAMES

FIGURE5. HINGE FORMATION IN (A) 5, 10 AND 15 STORIED FBD FRAME; (B) 5, 10 AND 15 STORIED PBPD FRAME;

\section{COST COMPARISON}

In this section, a cost comparison of the study frame when designed by FBD method, as well as PBPD method, has been presented. The rate of Structural steel without fabrication and connection costs is taken as 50 $₹ / \mathrm{kg}$. It is seen from Table 6 that the PBPD method is costlier than FBD method for smaller storey heights. As the storey height increases, the difference in cost goes on reducing. For the 15 storied frame, both the methods give the almost same cost. The fact that PBPD method gives a better seismic performance and prevents total collapse (which is reflected from fig. 4 and fig. 5) should supplement the cost-effectiveness. 
TABLE 6. COST COMPARISON OF THE STUDY FRAMES

\begin{tabular}{|l|l|l|l|}
\hline $\begin{array}{l}\text { No. of } \\
\text { Stories }\end{array}$ & $\begin{array}{l}\text { Cost of FBD } \\
\text { Frame(₹) }\end{array}$ & $\begin{array}{l}\text { Cost of PBPD } \\
\text { Frame (₹) }\end{array}$ & $\begin{array}{l}\text { Percentage } \\
\text { difference }\end{array}$ \\
\hline 5 & 338351 & 434115 & 28 \\
\hline 10 & 940599 & 1016615 & 8 \\
\hline 15 & 1775422 & 1783770 & 0.4 \\
\hline
\end{tabular}

\section{Conclusions}

Following conclusions were drawn from this comparative study between the PBPD and FBD method applied to CBF's of different storey heights.

- The lateral load distribution in PBPD method is more proper than FBD method.

- The braces are lighter, and columns are heavier in case of PBPD method.

- Total collapse can be prevented in PBPD method as no hinges are developed in columns.

- Although the PBPD method is not economical for low rise structures, it gains cost-effectiveness for high rise or taller structures.

\section{REFERENCES}

[1] S.C. Goel, S.H. Chao, Performance based Plastic Design: Earthquake Resistant Steel Structures, first ed., International Code Council, Illinois, 2008.

[2] S.C. Goel, W.C. Liao, S.H. Chao, M.R. Bayat, "Performance Based Plastic Design (PBPD) Method for Earthquake Resistant Structures: An Overview" Journal of the Structural Design of Tall and Special Buildings 19, 115-137, and 2010. https://doi.org/10.1002/tal.547.

[3] S.H. Chao, M.R.Bayat, S.C. Goel, "Performance Based Plastic Design of Steel Concentric Braced Frames for enhanced confidence level" in 2008 The 14th World Conference on Earthquake Engineering, Beijing, China, 2008.

[4] S.H. Chao, S.C. Goel, "A seismic design method for Steel Concentric Braced Frames for Enhanced Performance", in 2006 , Proceedings of fourth International Conference on Earthquake Engineering, Taipei, Taiwan, 2006

[5] S. P. Dalal, D. Patolia, P. Dalal, "Performance Based Plastic Design of Concentric Braced Frame attuned with Indian Standard Code and its Seismic Performance Evaluation", J. Materials and Engineering Structures 2 (2015) 168-179.

[6] IS 1893:2002, Indian Standard Criteria for Earthquake Resistant Design of Structures.

[7] S.H. Chao, S.C. Goel, S.S. Lee, "A Seismic Design Lateral Force Distribution Based On Inelastic State Of Structures", Earthquake Spectra 23-3 (2007) 547-569, DOI: 10.1193/1.2753549.

[8] S.P. Dalal, P.D. Dalal, A.K.Desai, "Effect of increasing Ductility factors on the Performance of a Steel Moment Resisting Frame designed by the Performance Based Plastic Designed method attuned with Indian code of Practice", Procedia Engineering, 173 (2017) 1862-1869. https://doi.org/10.1016/j.proeng.2016.12.238.

[9] IS 800:2007, Indian Standard General Construction in Steel, Code of Practice, Bureau of Indian Standards, New Delhi, India.

[10] S.P. Dalal, S.A.Vasanwala, A.K. Desai, "Comparison of Elastic Design and performance Based Plastic Design Method based on the Inelastic Response Analysis using SAP 2000", International Journal of Computer Applications 45-9 (2012) 1-13. DOI: 10.5120/6805-9144.

[11] ATC 40, Applied Technology Council, Seismic Evaluation and retrofitting of Concrete Buildings, 1(1996) 